\title{
ANALISIS PENGARUH TINGKAT PENDIDIKAN, ANGKATAN KERJA DAN PENGELUARAN PEMERINTAH TERHADAP PDRB DI PROVINSI SUMATERA SELATAN
}

\author{
ANAL YSIS OF EFFECT OF EDUCATION LEVEL, LABOR FORCE \\ AND GOVERNMENT EXPENDITURES ON GRDP \\ IN SOUTH SUMATERA PROVINCE
}

\author{
Riza Fahlewi ${ }^{1}$, Retno Riki Chairul Amri ${ }^{2}$, Adesy Mayang Sari ${ }^{3}$ \\ Sekolah Tinggi Ilmu Ekonomi dan Bisnis Prana Putra ${ }^{1,2,3}$ \\ Rizapahlewi@stiebipranaputra.ac.id ${ }^{1}$
}

\begin{abstract}
Economic growth measures the performance of an economy's development from one period to the next. The research objective was to analyze the effect of education level, labor force and government expenditures on GRDP in South Sumatera Province. The data used was secondary data from Revenue Office of Financial Management and Regional Assets and Central Bureau of Statistics (BPS) South Sumatera Province for 6 years (2013-2018). It was concluded that the variables of education has not significant effect on GRDP, while labor force, government expenditureshas significant effect on GRDP. The quantity of labor force contributes to economic growth and increased government expenditures should be balanced with the success of development in various sectors and fields.
\end{abstract}

Keywords: GRDP, Education, Labor Force, Government Expenditures

\begin{abstract}
ABSTRAK
Pertumbuhan ekonomi mengukur prestasi dari perkembangan suatu perekonomian dari suatu periode ke periode berikutnya. Tujuan penelitian ini adalah untuk menganalisa pengaruh tingkat pendidikan, tenaga kerja dan pengeluaran pemerintah atas GRDP di Provinsi Sumatera Selatan. Data yang digunakan adalah data sekunder dari kantor pendapatan manajemen keuangan dan aset daerah dan Biro Pusat Statistik (BPS) Provinsi Sumatera Selatan selama 6 tahun (2013-2018). Disimpulkan bahwa variabel pendidikan tidak berpengaruh signifikan terhadap GRDP, sementara angkatan kerja, pemerintah expenditureshas berpengaruh signifikan terhadap GRDP. Kuantitas tenaga kerja berkontribusi terhadap pertumbuhan ekonomi dan peningkatan belanja pemerintah harus seimbang dengan keberhasilan pembangunan di berbagai sektor dan bidang.
\end{abstract}

Kata Kunci: GRDP, Pendidikan, Angkatan Kerja, Pengeluaran Pemerintah 


\section{PENDAHULUAN}

Pada hakekatnya pembangunan ekonomi merupakan usaha dan kebijakan yang bertujuan untuk meningkatkan taraf hidup masyarakat, memperluas kesempatan kerja, meningkatkan pemerataan distribusi pendapatan masyarakat, memperlancar hubungan ekonomi, serta mengusahakan pergeseran kegiatan ekonomi dari sektor primer ke sektor sekunder maupun sektor tersier (Sukirno, 2005). Pertumbuhan ekonomi mengukur prestasi dari perkembangan suatu perekonomian dari suatu periode ke periode berikutnya. Dari satu periode ke periode lainnya kemampuan suatu Negara untuk menghasilkan barang dan jasa akan meningkat yang disebabkan oleh faktor-faktor produksi yang selalu mengalami pertambahan dalam jumlah dan kualitasnya.

Dalam analisis makro, tingkat pertumbuhan ekonomi yang dicapai oleh suatu Negara diukur dari perkembangan pendapatan nasional riil yang dicapai suatu Negara/daerah (Sukirno, 2005).Kemajuan dibidang ekonomi ini merupakan unsur penting dari setiap pembangunan yang dibutuhkan setiap daerah, dan menjadi suatu tuntutan yang wajar bagi setiap orang, akan tetapi pembangunan bukan semata-mata sebuah fenomena ekonomi, namun merupakan sebuah proses multi dimensi yang melibatkan reorganisasi dan reorientasi dari seluruh sistem sosial ekonomi yang ada (Arifin, 2007).

Salah satu untuk mengukur keberhasilan pembangunan dalam suatu Negara adalah pertumbuhan ekonomi.Pertumbuhan itu sendiri dapat diartikan sebagai gambaran mengenai dampak dari kebijakan-kebijakan pemerintah yang dilaksanakan dalam bidang ekonomi. Pertumbuhan ekonomi pada dasarnya merupakan suatu proses penggunaan faktor-faktor produksi untuk menghasilkan barang dan jasa (output). Pada akhirnya proses ini akan menghasilkan suatu aliran balas jasa terhadap faktor produksi yang dimiliki oleh penduduk. Laju pertumbuhan ekonomi merupakan suatu indikator ekonomi makro, yang menggambarkan seberapa jauh keberhasilan pembangunan suatu daerah dalam periode waktu tertentu. Rachman (2016) menjelaskan bahwa penurunan PDRB di Sumatera Selatan disebabkan beberapa hal yaitu penurunan pada sektor pertanian, kondisi itu ditenggarai sebagai dampak penurunan harga komoditas pertanian andalan (seperti padi dan jagung), sektor kedua yang mengalami penurunan adalah perkebunan dan perikanan, dimana harga komoditas tersebut juga anjlok. Ketika harga komoditas tersebut anjlok maka sangat berpengaruh terhadap perekonomian Sumatera Selatan. Hal tersebut dikarenakan Sumatera Selatan baru sampai pada tahap bahan baku, sedangkan hilirisasi untuk komoditas itu belum berjalan.

Ada banyak faktor yang mempengaruhi pertumbuhan PDRB dan melihat dari beberapa penelitian terdahulu maka peneliti tertarik untuk membahas beberapa faktor diantaranya tingkat pendidikan, dimana pertumbuhan PDRB erat hubungannya dengan sumber daya manusia, hubungan tersebut menunjukkan suatu keharusan bahwa sumber daya manusia yang berkualitas dapat menumbuhkan iklim bisnis yang sehat dan kondusif bagi pertumbuhan ekonomi. Faktor berikutnya yang juga berpengaruh terhadap pertumbuhan PDRB yaitu angkatan kerja karena parstisipasi aktif masyarakat akan mempercepat pembangunan ekonomi, untuk mendukung pelaksanaan pembangunan diperlukan kualitas dan kuantitas tenaga 
kerja sebagai Sumber Daya Manusia (SDM). Faktor lainnya yang juga mempengaruhi yaitu pengeluaran pemerintah, peningkatan pengeluaran pemerintah akan menyebabkan semakin meningkatkan pendapatan daerah, karena peningkatan agregat demand akan mendorong kenaikan investasi dan pada akhirnya menyebabkan kenaikan produksi.

Dari latar belakang dan permasalahan yang timbul, Peneliti tertarik untuk mengetahui sejauh mana faktor tingkat pendidikan, angkatan kerja dan pengeluaran pemerintah mempengaruhi PDRB Provinsi Sumatera selatan dan penelitian ini bertujuan untuk mengkaji faktor penentu Pertumbuhan Produk Domesik Regional Bruto (PDRB) di Provinsi Sumatera Selatan.

$\begin{array}{lcr}\text { Menurut } & \text { Sukirno } & \text { (2000) } \\ \text { Pertumbuhan } & \text { ekonomi } & \text { adalah } \\ \text { perkembangan } & \text { kegiatan } & \text { dalam } \\ \text { perekonomian } & \text { yang menyebabkan }\end{array}$
perekonomian yang menyebabkan barang dan jasa yang diproduksi dalam masyarakat bertambah dan kemakmuran masyarakat meningkat.Pertumbuhan ekonomi adalah sebagian dari perkembangan kesejahteraan masyarakat yang diukur dengan besarnya pertumbuhan domestic regional bruto perkapita (Zaris, 2000), pertumbuhan ekonomi berarti perkembangan kegiatan dalam perekonomian yang menyebabkan barang dan jasa yang diproduksi dalam masyarakat (Sukirno, 2004). Pertumbuhan ekonomi adalah kenaikan kapasitas dalam jangka panjang dari Negara yang bersangkutan untuk menyediakan berbagai barang ekonomi kepada penduduknya. Samuelson (2005) mendefinisikan bahwa pertumbuhan ekonomi menunjukkan adanya perluasan atau peningkatan dari Gross Domestic Product potensial/output dari suatu Negara.
Pertumbuhan ekonomi tinggi dalam era ekonomi daerah juga merupakansalah satu tujuan perekonomian suatu wilayah.Banyak faktor yang mempengaruhi pertumbuhan ekonomi suatu wilayah.Salah satu faktor yang mempengaruhi pertumbuhan ekonomi adalah sumber daya manusia (pendidikan).Sektor pendidikan dianggap memainkan peran utama untuk membentuk kemampuan sebuah Negara berkembang untuk menyerap teknologi modern dan mengembangkan kapasitas produksi agar tercipta pertumbuhan serta pembangunan yang berkelanjutan (Todaro, 2006).

$$
\text { Menurut Sukirno (2004) }
$$

pendidikan merupakan satu investasi yang sangat berguna untuk pembangunan ekonomi.Dengan demikian pendidikan dapat dimasukkan sebagai investasi pembangunan yang hasilnya dapat dinikmati dikemudian hari.ini menunjukkan bahwa pendidikan memiliki peranan penting. Sedangkan Samuelson \& Nordhaus (2001) menyebutkan bahwa input tenaga kerja terdiri dari kuantitas dan keterampilan tenaga kerja. Banyak ekonom percaya bahwa kualitas input tenaga kerja yakni keterampilan, pengetahuan dan disiplin tenaga kerja merupakan elemen penting dalam peningkatan PDRB suatu daerah.

Menurut tingkat pendidikannya, penduduk dapat dikelompokkan menjadi penduduk yang buta huruf dan yang melek huruf. Penduduk yang melek huruf dapat dikelompokkan lagi menurut tingkat pendidikannya, tidak tamat Sekolah Dasar, tamat Sekolah Dasar, tamat Sekolah Menengah Pertama, tamat Sekolah Menengah Atas, tamat Akademi/Perguruan Tinggi. Mulai tahun 2013 Departemen Pendidikan Nasional gencar menggalakkan program wajib belajar 12 tahun yaitu SD, SMP dan SMA. 
Program ini mewajibkan setiap warga untuk melaksanakan sekolah selama 12 tahun, hal ini bertujuan agar kualitas sumber daya manusia Indonesia tidak kalah bersaing dengan Negara lain.

Pendidikan bukan saja akan melahirkan Sumber Daya Manusi (SDM) berkualitas, memiliki pengetahuan dan keterampilan serta menguasai teknologi, tetapi juga dapat menumbuhkan iklim bisnis yang sehat dan kondusif bagi pertumbuhan ekonomi, Karena itu, investasi dibidang pendidikan tidak saja faedah bagi perorangan, tetapi juga bagi komunitas bisnis dan masyarakat umum.

Angkatan kerja adalah penduduk usia produktif yang berusia 15-64 tahun yang sudah mempunyai pekerjaan tetapi sementara tidak bekerja, maupun yang sedang aktif mencari pekerjaan. Selain angkatan kerja ada pula yang bukan angkatan kerja yaitu mereka yang berumur 10 tahun $k e$ atas yang kegiatannya hanya bersekolah, mengurus rumah tangga dan sebagainya.

Pertumbuhan Angkatan Kerja (AK) secara tradisional dianggap sebagai salah satu faktor positif yang memacu pertumbuhan ekonomi (Todaro, 2000) ,jumlah tenaga kerja yang lebih besar berarti akan menambah tingkat produksi, sedangkan pertumbuhan penduduk yang lebih besar berarti ukuran pasar domestiknya lebih besar. Meski demikian hal tersebut masih dipertanyakan apakah benar laju pertumbuhan penduduk yang cepat benar-benar akan memberikan dampak positif atau negatif dari pembangunan ekonominya. Pengaruh positif atau negatif dari pertumbuhan penduduk tergantung pada kemampuan system perekonomian daerah tersebut dalam menyerap dan secara produktif memanfaatkan pertambahan tenaga kerja tersebut. Kemampuan tersebut dipengaruhi oleh tingkat dan jenis akumulasi modal dan tersedianya input dan faktor penunjang seperti kecakapan manajerial dan administrasi.

Angkatan kerja yang homogeny dan tidak terampil dianggap bisa bergerak dan beralih dari sektor tradisional ke sektor modern secara lancar dan dalam jumlah terbatas.Dalam keadaan demikian penawaran tenaga kerja mengandung elastisitas yang tinggi, meningkatnya permintaan atas tenaga kerja bersumber pada ekspansi kegiatan sektor modern. Dengan demikian salah satu faktor yang berpengaruh terhadap pertumbuhan PDRB adalah tenaga kerja.

Suatu fungsi produksi suatu barang atau jasa tertentu (q) adalah $\mathrm{q}=\mathrm{f}$ $(\mathrm{K}, \mathrm{L})$ dimana $\mathrm{K}$ merupakan modal dan $\mathrm{L}$ adalah tenaga kerja yang memperlihatkan jumlah maksimal suatu barang atau jasa yang dapat diproduksi dengan menggunakan kombinasi alternatif antara $\mathrm{K}$ dan $\mathrm{L}$ maka apabila salah satu masukan ditambah satu unit tambahan dan masukan lainnya dianggap tetap akan menyebabkan tambahan dan masukan lainnya dianggap tetap akan menyebabkan tambahan keluaran yang dapat diproduksi. Tambahan keluaran yang diproduksi inilah yang disebut dengan produk fisik marginal (Marginal Physical Product).

Menurut Badan Pusat Statistik (BPS), penduduk berumur 10 tahun ke atas terbagi sebagai angkatan kerja dan bukan angkatan kerja. Angkatan kerja dikatakan bekerja bila mereka melakukan pekerjaan dengan maksud memperoleh atau membantu memperoleh pendapatan atau keuntungan dan lamanya bekerja paling sedikit satu jam secara kontinu selama satu minggu yang lalu. Sedangkan penduduk yang tidak bekerja tapi sedang mencari pekerjaan disebut 
menganggur. Tenaga kerja adalah mencakup penduduk yang sudah atau sedang bekerja, sedang mencari pekerjaan dan melakukan kegiatan lain, seperti bersekolah dan mengurus rumah tangga.Jumlah angkatan kerja yang bekerja merupakan gambaran kondisi dari lapangan kerja yang tersedia. Semakin bertambah besar lapangan kerja yang tersedia, maka akan menyebabkan semakin meningkatnya total produksi di suatu daerah.

Pengeluaran

pemerintah merupakan belanja pemerintah daerah yang manfaatnya satu anggaran dan akan menambah asset atau kekayaan daerah dan selanjutnya akan menambah belanja yang bersifat rutin seperti biaya pemeliharaan pada kelompok belanja administrasi umum.

Belanja modal adalah belanja yang dilakukan pemerintah yang menghasilkan aktiva tetap tertentu Nodiawan (2006) dan Terdapat tiga cara untuk memperoleh aset tetap pemerintah daerah yaitu membangun sendiri, menukarkan dengan asset tetap lainnya, atau juga dengan membeli. Pemerintah daerah biasanya melakukan dengan cara membangun sendiri atau membeli. Belanja modal memiliki karakteristik spesifik dan menunjukkan adanya berbagai pertimbangan dalam pengalokasiannya.

Belanja pada umumnya hanya digunakan disektor publik, tidak disektor bisnis. Belanja disektor publik terkait dengan penganggaran, yaitu menunjukkan jumlah uang yang telah dikeluarkan selama satu tahun anggaran. Belanja/biaya berdasarkan hubungannya dengan aktivitas dibagi dua, yaitu biaya langsung dan biaya tidak langsung. Pengklasifikasian tersebut berdasarkan PP No. 15 tahun 2000 tentang Pertanggungjawaban Pengelolaan Keuangan Daerah dan Kepmendagri No. 29 Tahun 2002 yang kemudian direvisi menjadi PP No. 58 Tahun 2005 tentang Pengelolaan Keuangan Daerah dan Permendagri No. 59 Tahun 2007 sebagai revisi Permendagri No. 13 Tahun 2006 tentang Pedoman Pengelolaan Keuangan Daerah.

Pengeluaran pemerintah adalah hal yang sangat penting karena menyangkut output yang dihasilkan untuk kepentingan hajat hidup orang banyak. Apabila pemerintah telah menetapkan suatu kebijakan untuk membeli barang dan jasa, pengeluaran pemerintah mencerminkan biaya yang harus dikeluarkan untuk melaksanakan kebijakan tersebut. Pengeluaran yang dilakukan pemerintah menunjukan perannya dalam perekonomian. Dalam rangka mencapai kondisi masyarakat yang sejahtera menurut Dumairy (2011), pemerintah memiliki 4 peran yaitu: a) peran alokasi, yakni peranan pemerintah dalam mengalokasikan sumber daya ekonomi yang ada agar pemanfaatan bisa optimal dan mendukung efisiensi produksi, b) peran distribusi, yaitu peranan pemerintah dalam mendistribusikan sumber daya, kesempatan dan hal-hal ekonomi secara adil dan wajar, c) peran stabilitatif, yakni pernaan pemerintah dalam memelihara stabilitas perekonomian dan memulihkannya jika berada dalam keadaan equilibrium, d) peran dinamisatif, yaitu peranan pemerintah dalam menggerakakkan proses pembangunan ekonomi agar lebih cepat tumbuh, berkembang dan maju.

Pengeluaran pemerintah berupa pembayaran subsidi atau bantuan langsung kepada berbagai golongan masyarakat. Pemerintah mampu mempengaruhi tingkat pendapatan keseimbangan menurut dua cara yang terpisah. Pertama, pembelian pemerintah atas barang dan jasa $(\mathrm{G})$ 
atau pooling menghasilkan 90 observasi dengan fungsi persamaan data panelnya.

\section{HASIL DAN PEMBAHASAN Pengaruh Pendidikan terhadap PDRB}

Dari hasil regresi didapat bahwa pendidikan (X1)tidak berpengaruh negatif signifikanterhadap PDRB di 15 Kota/Kabupaten yang ada di provinsi Sumatera Selatan dengan regresi untuk $\mathrm{X}_{1}=0,025898$.

Berdasarkan hasil analisis data yang telah dilakukan dapat dijelaskan bahwa tingkat pendidikan tidak berpengaruh signifikan terhadap PDRB di Provinsi Sumatera Selatan. Artinya, bahwa rendahnya persentase tingkat pendidikan tidak akan menurunkan PDRB di Provinsi Sumatera Selatan. Dalam hal ini menunjukkan bahwa warga yang menamatkan pendidikannya pada jenjang SLTA dan yang sederajat sebagai indicator pendidikan, belum dapat menjadi tolak ukur yang tepat sebagai pendongkrak besarnya PDRB di Provinsi Sumatera Selatan.

Penelitian tentang pengaruh variabel Pendidikan terhadap PDRB sejalan dengan penelitian yang dilakukan Saraswati dan Cahyono (2014) yang mengungkapkan bahwa pendidikan tidak mempengaruhi PDRB di kota Surabaya, hal ini disebabkan masih kurangnya pemahaman masyarakat tentang pentingnya pendidikan dan merasa cukup hanya pada tamatan SLTA. Tidak adanya kemauan untuk melanjutkan pendidikan ke jenjang yang lebih tinggi.

\section{Pengaruh Angkatan Kerja terhadap PDRB}

Hasil regresi ditemukan bahwa angkatan kerja (X2) memberikan pengaruh yang negatif signifikan terhadap PDRB. Nilai koefisien regresi untuk X2 $=-0,563132$ dan probabilitas
$0,0016<0,05$. Hal ini menunjukan besarnya pengaruh variabel angkatan kerja terhadap penurunan PDRB, artinya apabila variabel angkatan kerja meningkat sebesar satu jiwa, maka PDRB akan menurun sebesar 0,563132\%. Selama periode 2013 sampai 2018 terjadi fluktuasi jumlah angkatan kerja di $15 \mathrm{Kota} / \mathrm{Kabupaten}$ di Provinsi Sumatera Selatan. Peningkatan jumlah angkatan kerja yang diiringi dengan peningkatan jumlah kesempatan kerja mengidentifikasikan bahwa kinerja perekonomian telah menghasilkan pasar angkatan kerja yang positif. Artinya, pertambahan supply angkatan kerja masih bisa diimbangi dengan pertambahan demand angkatan kerja. Hanya saja, pertambahan demand kesempatan kerja masih belum cukup optimal dengan menekan pertambahan supply angkatan kerja. Akibatnya, jumlah angkatan kerja masih jauh lebih tinggi dibanding jumlah kesempatan kerja. Sehingga angkatan kerja di Provinsi Sumatera selatan berpengaruh negatif terhadap PDRB.

$$
\text { Angkatan kerja di } 15
$$

Kota/Kabupaten di Provinsi Sumatera Selatan yang relatif tinggi pada tahun 2015 terletak dikota Palembang sebesar 672.459 juta jiwa. Angka angkatan kerja yang relatif rendah ada di Kota Pagar Alam sebanyak 65.785 juta jiwa, Kota Prabumulih sebesar 83.986 juta jiwa dan Kota Lubuklinggau 89.321 juta jiwa. Angkatan kerja terendah yang ada di kota-kota tersebut lebih banyak mengandalkan sektor pertanian, kehutanan dan perikanan sebagai sektor utama. Seperti Kota Pagar Alam yang lebih mengandalkan sector pertanian seperti kopi dan sayur mayur.

Boediono (1999) menyatakan bahwa meningkatnya output dapat dilakukan dengan meningkatkan keterampilan pekerja, penerapan system pembagian kerja yang tepat berdasarkan 
keterampilan pekerja dan penggunaan mesin-mesin yang dapat memudahkan dan mempercepat serta meningkatkan produktivitas tenaga kerja. Peningkatan dalam penggunaan tenaga kerja menandakan adanya kesempatan kerja sebagai akibat dari peningkatan output tersebut.

\section{Pengaruh Pengeluaran Pemerintah terhadap PDRB}

Hasil dari perhitungan regresi menunjukkan bahwa Pengeluaran Pemerintah $\left(\mathrm{X}_{3}\right)$ berpengaruh positif signifikan terhadap PDRB dengan koefisien regresi $=0,313238$ dan nilai probabilitasnya $0,0000<0,05$. Hal ini menunjukan besarnya pengaruh variabel pengeluaran pemerintah terhadap penurunan PDRB, artinya apabila variabel pengeluaran pemerintah meningkat sebesar satu milyar Rupiah, maka PDRB akan meningkat sebesar $0,313238 \%$, dengan asumsi variabel $\mathrm{X}_{1}$ dan $\mathrm{X}_{2}$ tetap.

Selain menerima pendapatan daerah dalam kegiatan sehari-harinya pemerintah Provinsi Sumatera Selatan melakukan kegiatan untuk menunjang pelaksanaan dan berjalannya kegiatan rutin dan pembangunan.

Tabel 4.3 menunjukkan bahwa Musi Banyuasin menempatkan posisi pertama dengan pengeluaran pemerintah tertinggi yaitu sebesar 3.794,7 milyar rupiah. Musi Banyuasin memberikan kontribusi terbesar bagi Provinsi Sumatera Selatan dikarenakan daerah ini merupakan penghasil tambang terbesar di Provinsi Sumatera Selatan.

\section{Dukungan}

pengeluaran

pemerintah dalam kegiatan pembangunan di Provinsi Sumatera Selatan dari tahun ke tahun semakin meningkat. Peningkatan pengeluaran pemerintah ini sebanding dengan hasil pembangunan yang dirasakan oleh masyarakat. Ini berarti bahwa dengan meningkatnya pengeluaran pemerintah maka akan menyebabkan meningkatnya pertumbuhan ekonomi. Hasil ini sesuai dengan teori Granger Causality (Yunianto, 2011) yang menyatakan bahwa terdapat hubungan timbal balik antara PDRB dengan total pengeluaran pemerintah daerah.

\section{Implikasi Hasil Penelitian}

Penelitian ini bertujuan untuk mengetahui pengaruh pendidikan, angkatan kerja dan pengeluaran pemerintah terhadap PDRB di 15 Kota/Kabupaten di Provinsi Sumatera Selatan. Dari hasil penelitian diperoleh bahwa pendidikan tidak berpengaruh terhadap PDRB, angkatan kerja berpengaruh negatif dan signifikan terhadap PDRB, pengeluaran pemerintah berpengaruh positif dan signifikan terhadap PDRB.

Dari hasil penelitian ini adalah meskipun pendidikan tidak berpengaruh terhadap PDRB namun tetap memiliki andil dalam upaya meningkatkan PDRB sebaiknya masyarakat yang ada di provinsi Sumatera Selatan sadar akan pendidikan sehingga masyarakat bersedia untuk melanjutkan pendidikan ke jenjang yang lebih tinggi yaitu perguruan tinggi. Pemerintah hendaknya juga mendukung perbaikan pendidikan ini, dengan meningkatkan akses masyarakat untuk meningkatkan pendidikannya ditingkat perguruan tinggi melalui pemberian beasiswa dari pemerintah. Hal ini dimaksudkan agar mereka yang awalnya berlatar belakang SLTA, tidak kalah bersaing dengan mereka berlatar belakang pendidikan perguruan tinggi. Sehingga, perbaikan kualitas manusia melalui pendidikan ini mampu meningkatkan penghasilan mereka kelak, dan pada akhirnya mampu meningkatkan PDRB. 
Meskipun angkatan kerja juga berpengaruh negatif tetapi upaya disini bisa dengan menyelenggarakan program-program peningkatan sumber daya manusia sehingga jumlah orang yang bekerja yang tersedia akan lebih memiliki potensi dan peluang untuk mendapatkan pekerjaan yang jauh lebih baik atau dapat membuka sendiri lapangan kerja, strategi ini dapat ditempuh dalam peningkatan angka angkatan kerja sehingga hasil produksi akan meningkat yang dalam hal ini diharapkan dapat mendorong peningkatan PDRB.

Memperbesar alokasi belanja modal secara signifikan setiap tahun anggaran melalui perencanaan belanja modal secara signifikan setiap tahun anggaran melalui perencanaan belanja modal rasional dan memberi dampak langsung terhadap peningkatan investasi pemerintah daerah serta pelayanan publik merupakan strategi yang dapat dilakukan guna perbaikan dan peningkatan realisasi belanja pemerintah.

\section{PENUTUP}

\section{Kesimpulan}

Dari hasil penelitian dapat disimpulkan bahwa :

Pertama, secara simultan didapatkan hasil :

1. Variabel Pendidikan $\left(\mathrm{X}^{1}\right)$ berpengaruh positif signifikan $(\alpha=$ $0,05)$ terhadap PDRB (Y) di Provinsi Sumatera Selatan.

2. Variabel Angkatan Kerja $\left(\mathrm{X}_{2}\right)$ berpengaruh positif signifikan $(\alpha$ $=0,05)$ terhadap PDRB (Y) di Provinsi Sumatera Selatan.

3. Variabel Pengeluaran Pemerintah $\left(\mathrm{X}_{3}\right)$ berpengaruh positif signifikan $(\alpha=0,05)$ terhadap PDRB (Y) di Provinsi Sumatera Selatan.
Kedua, secara parsial didapatkan hasil :

1. Variabel Pendidikan $\left(\mathrm{X}_{1}\right)$ tidak berpengaruh terhadap PDRB (Y)

2. Variabel Angkatan Kerja $\left(\mathrm{X}_{2}\right)$ memiliki pengaruh negatif dan signifikan terhadap PDRB (Y)

3. Variabel Pengeluaran Pemerintah $\left(\mathrm{X}_{3}\right)$ berpengaruh positif dan signifikan terhadap PDRB (Y).

\section{Saran}

Berdasarkan hasil penelitian serta kesimpulan yang telah diuraikan, maka diberikan beberapa saran sebagai berikut :

Pertama, perlunya peran pemerintah dalam peningkatan mutu pendidikan, dengan memberikan beasiswa kepada masyarakat yang tidak mampu serta kepada pelajar yang berprestasi, diharapkan juga pemerintah membuka akses masyarakat untuk meningkatkan pendidikannya ditingkat perguruan tinggi melalui pemberian beasiswa dari pemerintah.

Kedua, Peran pemerintah daerah diharapkan untuk terus mengupayakan peningkatan kualitas jumlah penduduk yang bekerja. Hal ini dikarenakan secara kuantitas jumlah penduduk yang bekerja memberikan kontribusi yang tinggi bagi pertumbuhan ekonomi. Peningkatan kualitas bisa dilakukan dengan memberikan pelatihan-pelatihan kewirausahaan non formal bagi masyarakat.

Ketiga, Pemerintah diharapkan perlu lebih meningkatkan pengeluaran pemerintah, maka akan meningkat pula PDRB, ini bukan berarti bahwa pengeluaran pemerintah harus ditingkatkan secara besar-besaran tanpa arah yang jelas, tetapi peningkatan pengeluaran pemerintah itu harus diimbangi dengan keberhasilan pembangunan diberbagai sektor dan bidang. 


\section{DAFTAR PUSTAKA}

Arifin, Z.(2007). Prinsip-prinsip Ekonomi Makro, Edisi Kelima, Jakarta; PT. Indeks

Dumairy. (2004). Perekonomian Indonesia. Jakarta: Erlangga

Nordiawan, D. (2006). Akuntansi Sektor Publik. Salemba Empat; Jakarta.

Rahman, A \& Edi K. (2016). Ekonomi Pertanian. ETD UGM

Samuelson. (2005). Ilmu Makro Ekonomi. PT. Media Global. Jakarta.

Sukirno, S. (2005). Mikro Ekonomi Teori Pengantar. Edisi Ketiga, Jakarta. PT Raja Grafindo Persada

Todaro M.P, Smith S.C, (2011). Pembangunan Ekonomi, Edisi Kesebelas : Jakarta (ID): Erlangga.

Zaris, R. (2000). Perspektif Daerah dalam Pembangunan Nasional. LPFE UI. Jakarta 